\title{
Reduced Behavioral Effects of Cocaine in Heterozygous Brain-Derived Neurotrophic Factor (BDNF) Knockout Mice
}

\author{
F Scott Hall*,', Jana Drgonova', Michelle Goeb', George R Uhl' \\ 'Molecular Neurobiology Branch, National Institute on Drug Abuse-IRP, NIHIDHHS, Baltimore, MD, USA
}

\begin{abstract}
Brain-derived neurotrophic factor (BDNF) affects the development of brain neurotransmitter systems, including dopamine and serotonin systems that are important for cocaine's rewarding and locomotor stimulatory properties. Human genomic markers within or near the BDNF locus have been linked to or associated with substance abuse. Post-mortem human brain specimens reveal individual differences in the levels of BDNF mRNA and in mRNA splicing patterns. To assess the effects of lifelong alterations in the levels of BDNF expression on a measure of psychostimulant reward, we have compared locomotor stimulant and rewarding effects of cocaine in heterozygous BDNF knockout mice with effects in their wild-type littermates. Heterozygous BDNF knockout mice displayed less locomotion during habituation and less locomotion after cocaine injections. Cocaine-conditioned place preferences were reduced in the BDNF heterozygotes. These mice displayed no significant difference from saline control values at a dose of $10 \mathrm{mg} / \mathrm{kg}$ s.c. cocaine, although they exhibited cocaine-induced preference at a $20 \mathrm{mg} / \mathrm{kg}$ dose. These data confirm important roles for BDNF in psychostimulant actions, presumably via neurotrophic effects on dopamine and serotonin systems. Furthermore, these data support suggestions that differences in human BDNF expression may underlie associations between markers near the human BDNF gene locus and drug addiction. Neuropsychopharmacology (2003) 28, I485-1490, advance online publication, 30 April 2003; doi:I0.1038/sj.npp. I300। 92
\end{abstract}

Keywords: transgenic mice; gene knockout; dopamine; serotonin; brain-derived neurotrophic factor; conditioned place preference

\section{INTRODUCTION}

The psychostimulant cocaine inhibits the reuptake of dopamine, serotonin, and norepinephrine by blocking their respective transporters (DAT, SERT, and NET). The resulting potentiation of neurotransmission, particularly dopaminergic neurotransmission, has been believed to mediate cocaine's rewarding (Kuhar et al, 1991) and locomotor stimulant effects (Giros et al, 1996). However, dopamine transporter knockout mice exhibit normal or near-normal cocaine reward (Rocha et al, 1998; Sora et al, 1998); double knockout mice that lack both DAT and SERT lack cocaine reward and cocaine locomotor stimulation (Sora et al, 2001) and mice that lack both DAT and one copy of the 5HT1B serotonin receptor gene display normal cocaine-stimulated locomotion (Hall et al, submitted), which suggests a much more complicated picture of the substrates of cocaine-induced behavior; both serotonin and dopamine systems appear to be important determinants of

*Correspondence: Dr F Scott Hall, Molecular Neurobiology Branch, NIDA/IRP, NIH/DHHS, 5500 Nathan Shock Drive, Baltimore, MD 21224, USA, Tel: + I 4105502843 extl47, Fax: + | 4105502846 , E-mail: shall@intra.nida.nih.gov

Received 04 January 2002; revised 17 December 2002; accepted 18 February 2003

Online publication: 12 March 2003 at http://www.acnp.org/citations/ Npp031203368/default.pdf both cocaine reward and cocaine-stimulated locomotion. Genes that influence the development of both of these brain systems are thus especially attractive candidates for variation that might predispose to individual differences in locomotor and addictive processes, especially those triggered by psychostimulants.

Competition for limited quantities of neurotrophic factors, including brain-derived neurotrophic factor (BDNF) help (Oppenheim, 1991) determine the adult complements of specific neuronal populations (see Barde, 1994; Price and Willshaw, 2000 for a review). BDNF can also participate in activity-dependent synaptic plasticity (for a review, see Korte and Bonhoeffer, 1997) likely to contribute to specific neuroprotective and neurotrophic effects that include effects on survival of dopaminergic neurons in vitro (Hyman et al, 1991; Hyman et al, 1994; Son et al, 1999).

Human variation at the BDNF locus is therefore a strong candidate to contribute to individual differences in substance abuse vulnerability. Genomic markers within the human BDNF locus have been associated with substance abuse comorbidity in a population of French schizophrenic patients (Krebs et al, 2000). Genomic markers that flank the human BDNF locus display different frequencies in each of the two populations of polysubstance abusers compared to ethnically matched controls (Uhl et al, 2001). Initial results from RT-PCR amplification of BDNF transcripts from human brain samples indicate that there are substantial human individual quantitative and qualitative differences in 
the levels of BDNF mRNA, in use of alternative transcriptional start sites, and in the patterns of splicing the BDNF primary transcripts produced from these transcriptional start sites (Q-R Liu and GRU, in preparation).

Gene knockout studies of the BDNF locus might be highly informative about the potential influences of BDNF expression on responses to cocaine. Homozygous knockout mice that lack BDNF display substantial abnormalities, morbidity, and mortality. Homozygous BDNF knockouts display profound neuronal loss in regions including cerebellum (Carter et al, 2002), olfactory bulb (Linnarsson et al, 2000), visual cortex (Huang et al, 1999), and cochlea (Wiechers et al, 1999) and often die prior to their third postnatal week (Ernfors et al, 1994; for a review see Conover and Yancopoulos, 1997). By contrast, heterozygous BDNF knockout mice are viable, display roughly half of wild-type BDNF levels, and thus provide a potentially less confounded model of influences of lifelong variation at this locus for behavioral characterizations. Heterozygote mice display results equivalent to wild-type animals in tests of locomotor activity (Dluzen et al, 2001; MacQueen et al, 2001), exploration (MacQueen et al, 2001), sucrose ingestion (MacQueen et al, 2001), anxiety (Montkowski and Holsboer, 1997), forced swimming (MacQueen et al, 2001), and spatial learning (Korte et al, 1995). Heterozygous BDNF knockout mice do display altered hippocampal long-term potentiation (Korte et al, 1995; Montkowski and Holsboer, 1997), subtle alterations in sensory and nociceptive systems (Korte $e t$ al, 1995; MacQueen et al, 2001), modest impairments in beam walking (Dluzen et al, 2001), altered learned helplessness responses (MacQueen et al, 2001), and reduced cocaineinduced locomotor sensitization (Horger et al, 1999). Given these relatively specific and subtle deficits heterozygous BDNF knockout mice provide a reasonable experimental model for behavioral studies.

Monoaminergic systems are subtly altered by reduced BDNF expression in BDNF knockout mice, just as monoamines and monoamine-associated behaviors are influenced by experimental BDNF administration (Siuciak et al, 1996; Siuciak et al, 1998; Horger et al, 1999). While dopamine neuronal counts are similar to wild-type values in developing BDNF homozygous knockouts (Ernfors $e t$ al, 1994), postnatal differences could well emerge as BDNF mRNA and protein levels increase over the first few weeks of life (Timmusk et al, 1994). Some evidence does support this idea of emerging alterations in BDNF heterozygous knockout mice as they age, including alterations in the striatonigral pathway (Jones et al, 1994), small increases in striatal tissue dopamine levels, and reduced potassium depolarization-induced release of dopamine from striatal slices prepared from heterozygote brains (Dluzen et al, 2001). BDNF modulation of dopaminergic function in knockouts is also supported by the findings that central BDNF infusions enhance cocaine's acute locomotor stimulation, locomotor sensitization that can be observed after repeated cocaine treatments, rates of responding for conditioned reinforcers, and the enhancement of conditioned reinforcement produced by cocaine administration (Horger et al, 1999).

In addition to changes in dopaminergic systems in BDNF knockout mice, there are also changes in serotonergic systems. Forebrain 5-HT levels are reduced in older BDNF heterozygous knockouts (Lyons et al, 1999). Microdialysis studies reveal increased extracellular striatal 5-HT levels and evidence of reduced serotonin uptake (Mathews et al, 1991). Serotonin receptor levels are affected in BDNF heterozygotes in a region- and subtype-dependent manner (Lyons et al, 1999): 5-HT 1B and 5-HT 2A receptors are increased in the cortex and hypothalamus, while 5-HT 2C receptors are increased in the hypothalamus but reduced in the hippocampus. The increase in c-FOS expression induced in wild-type mice by dexfenfluramine is also reduced by heterozygous BDNF knockout (Lyons et al, 1999).

We now report the extension of these ideas with the study of baseline and cocaine-stimulated locomotion and reward function in heterozygous BDNF knockout mice. The striking effects that we report here, in contrast to the modest sizes of other subtle sensory and motor alterations noted for these animals, suggest the importance of BDNF for these processes. These results also provide a reference point for the sorts of behavioral differences that human allelic variation at the BDNF locus might confer.

\section{MATERIALS AND METHODS}

\section{Animals}

Heterozygous and wild-type BDNF mutant mice (Jackson Laboratories, Bar Harbor, ME) were generated by wildtype $\times$ heterozygote crosses. These mice, in which Exon $V$ of the BDNF gene is deleted, resulting in half normal expression of BDNF mRNA, were originally described by Ernfors (Ernfors et al, 1994). In these mice the homozygous condition is lethal; therefore, the wild-type $\times$ heterozygote breeding strategy was adopted. Mice were genotyped by PCR using the following primers: BDNF132 GGGAACTTCCTGACTAGGGG, BDNF133 ATGAAAGAAGTAAACGTCCAC, and BDNF134 CCAGCAGAAAGAGTAGAGGAG (as described in Dluzen et al, 1999). The mice were housed at $24^{\circ} \mathrm{C}$ with a 12/12-h light-dark cycle and ad libitum access to food and water. All experiments were conducted on mice between 12 and 20 weeks of age. Mice were weighed prior to the beginning of the experiments and tested for motor ability in the rotorod test. Subsequently, mice were tested for the behavioral effects of cocaine on reward, in the conditioned place preference paradigm, and then for basal and cocaine-stimulated locomotion.

\section{Conditioned Place Preference}

Reward was assessed by conditioned place preference testing using a two compartment Plexiglas chamber (Sora et al, 2001). Briefly, one compartment $\left(18 \times 18 \times 18 \mathrm{~cm}^{3}\right)$ had a wire mesh floor $(1.3 \mathrm{~cm}$ grids) mounted over Plexiglas, and the other compartment $(18 \times 18 \times 18 \mathrm{~cm})$ had corncob bedding on a smooth Plexiglas floor. A removable Plexiglas wall separated the two sides. For preand postconditioning test sessions, a $5 \mathrm{~cm}$ opening in the center wall allowed access to both compartments. During the conditioning sessions the opening was eliminated to restrict animals to a single compartment. Locomotion and time spent in each compartment was recorded using an Optovarimax animal activity monitoring apparatus (Co- 
lumbus Instruments, Columbus, $\mathrm{OH}$ ). Conditioned place preferences were assessed by determination of compartment preference in three phases. Initial preference was determined as the side in which a mouse spent more than $600 \mathrm{~s}$ out of a $20 \mathrm{~min}$ trial. Conditioning was conducted over a 2-day period in which cocaine hydrochloride $(10 \mathrm{mg} / \mathrm{kg}$ s.c.) was administered to the animal when it was confined for $20 \mathrm{~min}$ in the initially nonpreferred compartment and saline administered to the animal when restricted for $20 \mathrm{~min}$ to the initially preferred compartment. Animals received two conditioning sessions per day, counterbalanced between saline and cocaine for a total of two saline pairings and two cocaine pairings. Conditioned place preference assessment followed the last conditioning session and the last injection by $24 \mathrm{~h}$. Time spent in the drug-paired compartment was compared to the preconditioning values obtained on initial assessments.

\section{Locomotor Testing}

Locomotor activity was assessed as the total distance traveled. Distance was calculated from measurement of infrared beam breaks by mice placed individually in $46 \times 25 \times 19 \mathrm{~cm}^{3}$ clear plastic cages in Optovarimax activity monitors (Columbus Instruments, Columbus, $\mathrm{OH}$ ) under dim light, sound-attenuated conditions. An initial $3 \mathrm{~h}$ activity test was conducted under novel conditions. Subsequently mice were tested for cocaine-stimulated activity. After habituation to the apparatus for $1 \mathrm{~h}$ mice were injected with cocaine hydrochloride $(0,5,10$, or $20 \mathrm{mg} / \mathrm{kg} \mathrm{s.c.})$, and the distance traveled was monitored for an additional $2 \mathrm{~h}$. Doses were tested using a within-subjects design, doses counterbalanced across testing days, and at least $48 \mathrm{~h}$ separating each testing day.

\section{Drugs}

Cocaine $\mathrm{HCl}$ (NIDA IRP Drug Supply Program) was dissolved in saline and administered s.c. in a volume of $1.0 \mathrm{ml} / \mathrm{kg}$.

\section{Statistical Analyses}

Weight data were subjected to ANOVA with the betweensubjects factors of GENOTYPE $(+/+v s+I-)$ and SEX (male $v s$ female). Rotorod data were subjected to ANOVA with the between-subjects factor of GENOTYPE and the within-subjects factor of TRIAL.

Conditioned place preference was defined by the difference between the time spent on the initially nonpreferred side postconditioning and the time spent on that side preconditioning. These data were then subjected to ANOVA with the between-subjects factors of GENOTYPE and DOSE.

Baseline locomotor activity data were analyzed by ANOVA with the between-subjects factor of GENOTYPE and the within-subjects factor of TIME, with the data divided into 10-min bins. For cocaine-stimulated locomotion the distance traveled was summed over each test session and analyzed by ANOVA with the between-subjects factor of GENOTYPE and the within-subjects factor of cocaine DOSE. In addition, each individual dose was analyzed in a separate ANOVA with the between-subjects factor of GENOTYPE and the within-subjects factor of TIME, with the data divided into 10-min bins.

\section{RESULTS}

\section{Baseline Weight and Gross Motor Behavior}

Mice were weighed prior to the beginning of behavioral experiments. Male BNDF $+/+$ mice weighed $32.1 \pm 1.5 \mathrm{~g}$, while male BDNF $+/-$ mice weighed $41.9 \pm 1.6 \mathrm{~g}$. A similar increase in weight in females was observed where the female BDNF $+I+$ mice weighed $26.0 \pm 0.8 \mathrm{~g}$ and the female BDNF $+/-$ mice weighed $31.9 \pm 1.1 \mathrm{~g}$. Thus, in addition to the significant effect of SEX in the ANOVA $(\mathrm{F}(1,63)=34.5$, $p<0.0001)$, there was also a significant effect of GENOTYPE $(\mathrm{F}(1,63)=32.9, p<0.0001)$.

In tests of the ability of mice to remain on an accelerating rotorod, there was no effect of GENOTYPE (data not presented). There was no gross ataxia or other marked motor impairment of these mice on observation (data not shown).

\section{Baseline Locomotion}

BDNF $+I-$ mice were less active than littermate wild-type BDNF $+/+$ mice in the first hour of a 3 -h locomotor habituation test (Figure 1: $\mathrm{F}(17,493)=1.7, p<0.04$ ). The difference in locomotion between genotypes was eliminated at time periods following the first hour of within-session habituation.

\section{Cocaine-Induced Locomotion}

The reduced locomotion observed in the first hour of baseline locomotor assessments was also observed in the 1$\mathrm{h}$ habituation periods prior to drug injections, but again had been eliminated by the end of the hour of habituation (time-course data not shown). This difference was not attenuated with repeated testing; it was present in each of the four preinjection habituation sessions (Figure 2).

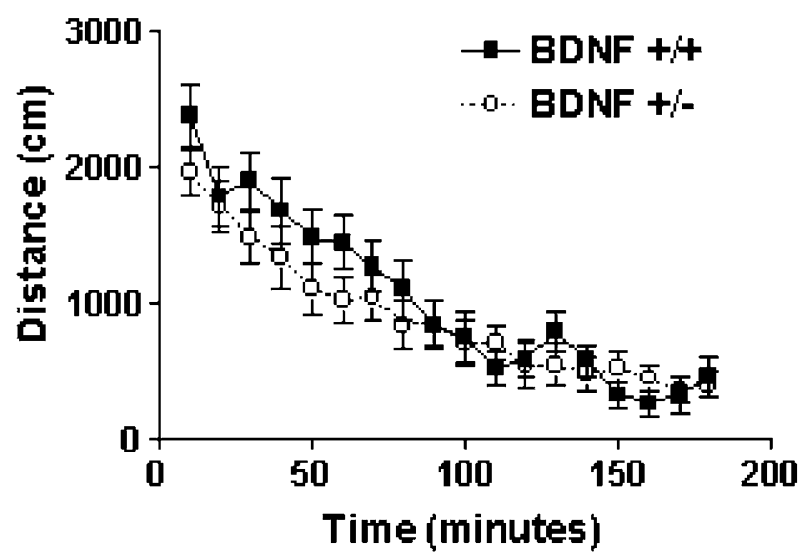

Figure I Time course of locomotor activity and habituation to a novel environment in BDNF $+/+$ and $+/-$ mice. Time course of locomotor activity in BDNF $+/+$ and $+/$ - expressed in terms of total distance traveled over the 3 -h session. Data expressed as mean \pm standard error of the mean. 


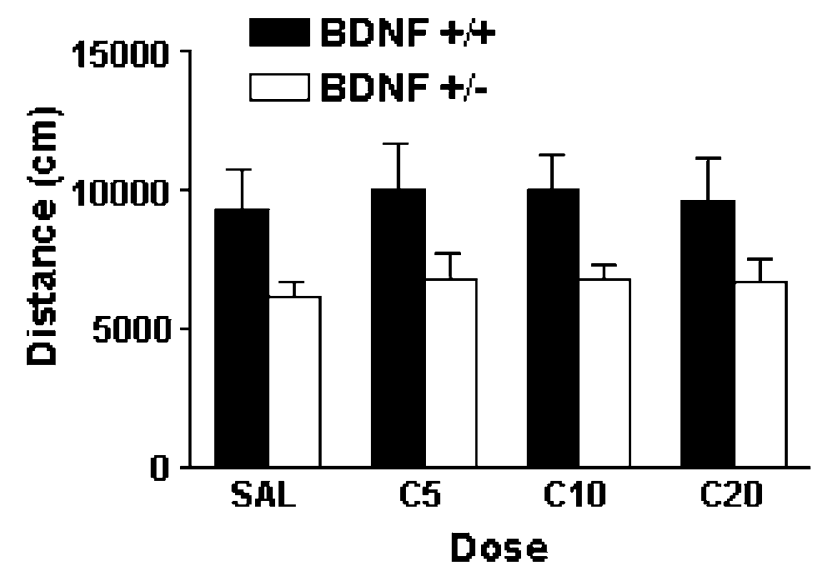

Figure 2 Total baseline locomotor activity in BDNF $+1+$ and $+1-$ mice for habituation testing prior to cocaine injection. Total locomotor activity in BDNF $+1+$ and $+1-$ mice expressed in terms of total distance traveled for the four habituation sessions prior to cocaine injection $(5,10$, and $20 \mathrm{mg} / \mathrm{kg}$ i.p. cocaine; $\mathrm{C} 5, \mathrm{Cl} 0$, and $\mathrm{C} 20$ respectively) or saline (SAL) injection. Data are presented in dose order, which was counterbalanced, not the order of testing. Data expressed as mean \pm standard error of the mean.

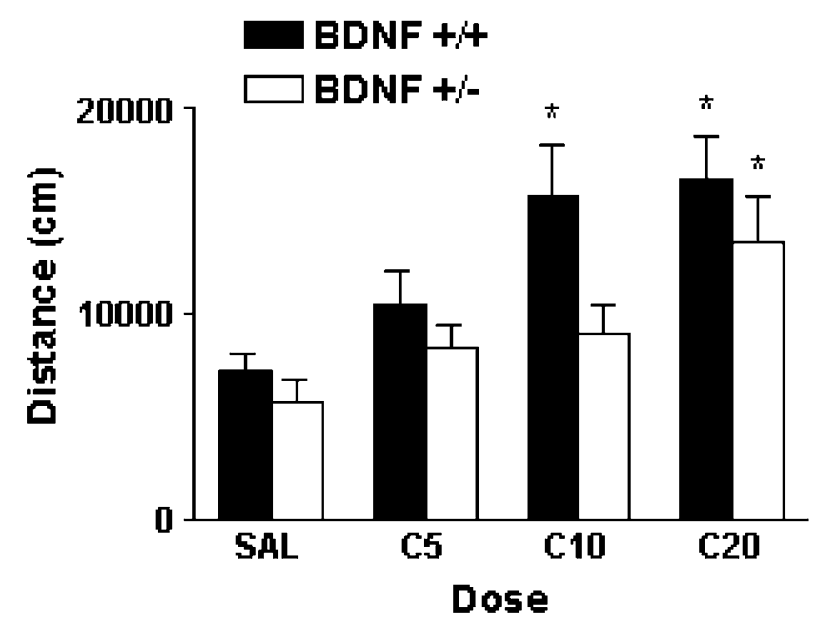

Figure 3 Cocaine-induced locomotor activity in BDNF $+1+$ and $+/-$ mice. Cocaine-induced locomotor activity in BDNF $+/+$ and $+/$ - mice expressed as the total distance traveled over $2 \mathrm{~h}$ of testing after the injection. Data expressed as mean \pm standard error of the mean. *Significant difference from saline based on Scheffe's post hoc comparison $(p<0.05)$.

ANOVA comparing GENOTYPE, HABITUATION, and TIME revealed a significant effect of GENOTYPE $(\mathrm{F}(1,29)=5.1, p<0.04)$. By the end of the habituation period there was no difference in activity between genotypes, so that after saline administration there was no statistically significant difference in activity between genotypes (Figure 3).

Both genotypes demonstrated significant dose-dependent effects of cocaine on locomotion (Figure 3; DOSE effect $\mathrm{F}(3,87)=11.3, p<0.0001)$. However, cocaine effects were reduced in $\mathrm{BDNF}+I-$ mice producing a statistically significant effect of GENOTYPE $(\mathrm{F}(1,29)=4.6, p<0.05)$. A $10 \mathrm{mg} / \mathrm{kg}$ dose of cocaine was sufficient to elevate locomotion in BDNF $+/+$ mice, while $20 \mathrm{mg} / \mathrm{kg}$ was necessary to increase locomotion in BDNF $+/-$ mice.

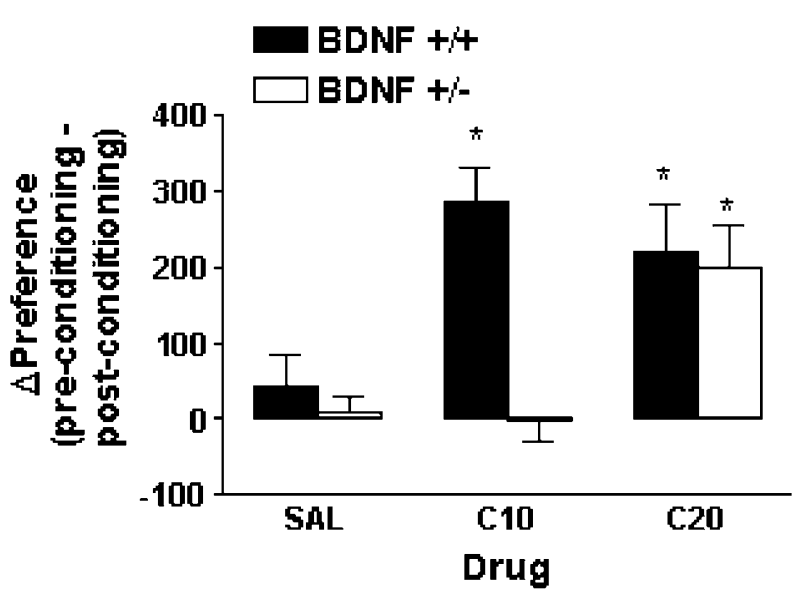

Figure 4 The conditioned place preference for cocaine is reduced in the $\mathrm{BDNF}+1-$ mice. Conditioned place preference induced by cocaine ( 10 and $20 \mathrm{mg} / \mathrm{kg}$, s.c.) in BDNF + / + and BDNF + / - mice expressed as the difference between the preconditioning preference and the postconditioning preference. BDNF $+/+$, but not BDNF $+/-$, mice displayed a significant effect of cocaine relative to saline treatment at the $10 \mathrm{mg} / \mathrm{kg}$ dose, while both genotypes displayed a significant difference at the $20 \mathrm{mg} /$ kg dose (*p<0.01 Scheffe's post hoc comparison).

\section{Cocaine-Induced Conditioned Place Preference}

Cocaine produced a significant place preference (Figure 4; DRUG $\mathrm{F}(2,89)=9.7, \quad p<0.01)$. There was an overall significant effect of GENOTYPE on cocaine conditioning $(\mathrm{F}(1,89)=9.4, p<0.01)$. The BDNF $+/-$ mice exhibited less preference for an environment previously paired with cocaine. This effect of GENOTYPE interacted with DRUG treatment $(\mathrm{F}(2,89)=6.3, p=0.01)$. Wild-type $\mathrm{BDNF}+/+$ mice displayed substantial preferences for cocaine-paired environments at both the 10 and $20 \mathrm{mg} / \mathrm{kg}$ doses of cocaine. Strikingly, however, heterozygous BDNF $+/-$ mice failed to show any significant preference for cocaine-paired environment at the $10 \mathrm{mg} / \mathrm{kg}$ dose of cocaine and required $20 \mathrm{mg} / \mathrm{kg}$ cocaine to produce a place preference equivalent to wildtype levels (Figure 4; post hoc Scheffe's comparisons, $p<0.01$ ).

\section{DISCUSSION}

These striking data can be discussed in relation to their implications for important BDNF roles in cocaine reward and locomotion, the relation between effects on reward and locomotor measures, and the way in which the current results might influence thinking about the role of BDNF variation in human addiction.

The rewarding effects of cocaine assessed in the conditioned place preference paradigm are attenuated in BDNF + I- mice. Cocaine-conditioned place preference was eliminated at the $10 \mathrm{mg} / \mathrm{kg}$ dose of cocaine. The reemergence of near-normal place preference at $20 \mathrm{mg} / \mathrm{kg}$ doses in the heterozygotes is consistent with this knockout producing a rightward shift in the dose-response curve for cocaine. The re-emergence of cocaine reward at $20 \mathrm{mg} / \mathrm{kg}$ doses suggests that it is unlikely that nonspecific learning deficits account for the findings at the lower cocaine doses, although some behavioral deficits have been documented in $\mathrm{BDNF}+/-$ mice (see Introduction). 
These changes in the conditioned place preference paradigm were strikingly similar to the effects of BDNF knockout on cocaine-induced locomotion. Locomotorstimulating effects of cocaine were reduced but not eliminated in BDNF $+/-$ mice with a similar dose-effect profile. Decreases in cocaine efficacy with reduced BDNF expression are consistent with observations that cocaine sensitization is delayed in the BDNF $+/-$ mice and with observations that BDNF administration enhances cocaine sensitization and conditioned reinforcement (Horger et al, 1999). These data add to initial suggestions that human allelic variation at a locus in or near the BDNF gene could contribute to individual differences in human addiction vulnerability (Krebs et al, 2000; Uhl et al, 2001).

The BDNF + I- mice studied here exhibited greater weights than wild-type littermates, as previously reported (Horger et al, 1999; Lyons et al, 1999; Kernie et al, 2000). These mice also exhibited reduced locomotion that has not been found in all locomotor assessments that have been previously reported (Horger et al, 1999; MacQueen et al, 2001). Previous authors have reported combined data from 12-h test periods (MacQueen et al, 2001) without timecourse analyses (Horger et al, 1999; Kernie et al, 2000). Since the locomotor differences observed in our studies were most pronounced at the beginning of each locomotor test, these differences would not be prominent without time-course analyses. In addition, the lack of any motor deficit in the rotorod test indicates that the small locomotor decreases observed here do not represent a gross, generalized motor incapacity.

BDNF affects many brain systems. Despite the plethora of effects that BDNF reduction can have, particularly in homozygous knockouts (Conover and Yancopoulos, 1997), the cumulative behavioral profiles that emerge from the studies of heterozygous BDNF knockout mice reveal relative specificity for the behavioral consequences of reduced BDNF expression. Since combined knockouts of DAT and SERT genes are required to eliminate cocaine reward (Sora et al, 2001) and since BDNF effects on both systems have been identified (Hyman et al, 1991; Hyman et al, 1994; Eaton et al, 1995; Mamounas et al, 1995; Son et al, 1999; Galter and Unsicker, 2000; Zhou and Iacovitti, 2000), the large effects of partial BDNF deletion on cocaine reward mechanisms might also be largely because of actions on both dopaminergic and serotonergic systems. The present experiments thus provide some indirect support for the idea that dopamine and serotonin functions are critical determinants of cocaine reward (Uhl et al, 2002). The current results thus identify the BDNF gene, because of its individual variations and its regulatory effects on systems that include both of these monoamine systems, as an important gene for cocaine reward and cocaine addiction.

\section{ACKNOWLEDGEMENTS}

We acknowledge financial support from the NIDA-IRP/ $\mathrm{NIH} / \mathrm{DHHS}$ and excellent animal care support from the Charles River/Triad animal care staff. Experiments were conducted under protocols approved by the NIDA-IRP Animal Care and Use Committee.

\section{REFERENCES}

Barde YA (1994). Neurotrophins: a family of proteins supporting the survival of neurons. Prog Clin Biol Res 390: 45-56.

Carter AR, Chen C, Schwartz PM, Segal RA (2002). Brain-derived neurotrophic factor modulates cerebellar plasticity and synaptic ultrastructure. J Neurosci 22: 1316-1327.

Conover JC, Yancopoulos GD (1997). Neurotrophin regulation of the developing nervous system: analyses of knockout mice. Rev Neurosci 8: 13-27.

Dluzen DE, Gao X, Story GM, Anderson LI, Kucera J, Walro JM (2001). Evaluation of nigrostriatal dopaminergic function in adult $+/+$ and +/- BDNF mutant mice. Exp Neurol 170: 121-128.

Dluzen DE, Story GM, Xu K, Kucera J, Walro JM (1999). Alterations in nigrostriatal dopaminergic function within BDNF mutant mice. Exp Neurol 160: 500-507.

Eaton MJ, Staley JK, Globus MY, Whittemore SR (1995). Developmental regulation of early serotonergic neuronal differentiation: the role of brain-derived neurotrophic factor and membrane depolarization. Dev Biol 170: 169-182.

Ernfors P, Lee KF, Jaenisch R (1994). Mice lacking brain-derived neurotrophic factor develop with sensory deficits. Nature 368: 147-150.

Galter D, Unsicker K (2000). Brain-derived neurotrophic factor and trkB are essential for cAMP-mediated induction of the serotonergic neuronal phenotype. J Neurosci Res 61: 295-301.

Giros B, Jaber M, Jones SR, Wightman RM, Caron MG (1996). Hyperlocomotion and indifference to cocaine and amphetamine in mice lacking the dopamine transporter. Nature 379: 606-612.

Hall FS, Goeb M, Li XF, Hogatt H, Axelrad S, Sora I et al (submitted) Cocaine's locomotor stimulation can be restored to dopamine transporter knockout mice by heterozygous serotonin receptor $1 \mathrm{~B}$ deletion.

Horger BA, Iyasere CA, Berhow MT, Messer CJ, Nestler EJ, Taylor JR (1999). Enhancement of locomotor activity and conditioned reward to cocaine by brain-derived neurotrophic factor. $J$ Neurosci 19: 4110-4122.

Huang ZJ, Kirkwood A, Pizzorusso T, Porciatti V, Morales B, Bear MF, Maffei L, Tonegawa S (1999). BDNF regulates the maturation of inhibition and the critical period of plasticity in mouse visual cortex. Cell 98: 739-755.

Hyman C, Hofer M, Barde YA, Juhasz M, Yancopoulos GD, Squinto SP, Lindsay RM (1991). BDNF is a neurotrophic factor for dopaminergic neurons of the substantia nigra. Nature 350: 230-232.

Hyman C, Juhasz M, Jackson C, Wright P, Ip NY, Lindsay RM (1994). Overlapping and distinct actions of the neurotrophins BDNF, NT-3, and NT-4/5 on cultured dopaminergic and GABAergic neurons of the ventral mesencephalon. J Neurosci 14: $335-347$.

Jones KR, Farinas I, Backus C, Reichardt LF (1994). Targeted disruption of the BDNF gene perturbs brain and sensory neuron development but not motor neuron development. Cell 76: 989999.

Kernie SG, Liebl DJ, Parada LF (2000). BDNF regulates eating behavior and locomotor activity in mice. Embo J 19: 1290-1300.

Korte M, Bonhoeffer T (1997). Activity-dependent synaptic plasticity: a new face of action for neurotrophins. Mol Psychiatry 2: 197-199.

Korte M, Carroll P, Wolf E, Brem G, Thoenen H, Bonhoeffer T (1995). Hippocampal long-term potentiation is impaired in mice lacking brain- derived neurotrophic factor. Proc Natl Acad Sci USA 92: 8856-8860.

Krebs MO, Guillin O, Bourdell MC, Schwartz JC, Olie JP, Poirier MF, Sokoloff P (2000). Brain derived neurotrophic factor (BDNF) gene variants association with age at onset and therapeutic response in schizophrenia. Mol Psychiatry 5: $558-562$. 
Kuhar MJ, Ritz MC, Boja JW (1991). The dopamine hypothesis of the reinforcing properties of cocaine. Trends Neurosci 14: 299302.

Linnarsson S, Willson CA, Ernfors P (2000). Cell death in regenerating populations of neurons in BDNF mutant mice. Brain Res Mol Brain Res 75: 61-69.

Lyons WE, Mamounas LA, Ricaurte GA, Coppola V, Reid SW, Bora $\mathrm{SH}$ et al (1999). Brain-derived neurotrophic factor-deficient mice develop aggressiveness and hyperphagia in conjunction with brain serotonergic abnormalities. Proc Natl Acad Sci USA 96: 15239-15244.

MacQueen GM, Ramakrishnan K, Croll SD, Siuciak JA, Yu G, Young LT, Fahnestock M (2001). Performance of heterozygous brain-derived neurotrophic factor knockout mice on behavioral analogues of anxiety, nociception, and depression. Behav Neurosci 115: 1145-1153.

Mamounas LA, Blue ME, Siuciak JA, Altar CA (1995). Brainderived neurotrophic factor promotes the survival and sprouting of serotonergic axons in rat brain. J Neurosci 15: 7929-7939.

Mathews TA, Fedele DE, Mamounas LA, Lyons WE, Andrews AM (1991). Quantitative microdialysis for serotonin in BDNF knockout mice. Soc Neurosci Meeting Abstr, 806.20.

Montkowski A, Holsboer F (1997). Intact spatial learning and memory in transgenic mice with reduced BDNF. Neuroreport 8: 779-782.

Oppenheim RW (1991). Cell death during development of the nervous system. Annu Rev Neurosci 14: 453-501.

Price DJ, Willshaw DA (2000). Mechanisms of Cortical Development. Oxford University Press: Oxford.

Rocha BA, Fumagalli F, Gainetdinov RR, Jones SR, Ator R, Giros B et al (1998). Cocaine self-administration in dopamine-transporter knockout mice [see comments] [published erratum appears in Nat Neurosci 1998 Aug; 1(4): 330]. Nat Neurosci 1: 132-137.

Siuciak JA, Boylan C, Fritsche M, Altar CA, Lindsay RM (1996). BDNF increases monoaminergic activity in rat brain following intracerebroventricular or intraparenchymal administration. Brain Res 710: 11-20.

Siuciak JA, Clark MS, Rind HB, Whittemore SR, Russo AF (1998). BDNF induction of tryptophan hydroxylase mRNA levels in the rat brain. J Neurosci Res 52: 149-158.

Son JH, Chun HS, Joh TH, Cho S, Conti B, Lee JW (1999). Neuroprotection and neuronal differentiation studies using substantia nigra dopaminergic cells derived from transgenic mouse embryos. J Neurosci 19: 10-20.

Sora I, Hall FS, Andrews AM, Itokawa M, Li XF, Wei HB et al (2001). Molecular mechanisms of cocaine reward: combined dopamine and serotonin transporter knockouts eliminate cocaine place preference. Proc Natl Acad Sci USA 98: 5300-5305.

Sora I, Wichems C, Takahashi N, Li XF, Zeng Z, Revay R et al (1998). Cocaine reward models: conditioned place preference can be established in dopamine- and in serotonin-transporter knockout mice. Proc Natl Acad Sci USA 95: 7699-7704.

Timmusk T, Belluardo N, Persson H, Metsis M (1994). Developmental regulation of brain-derived neurotrophic factor messenger RNAs transcribed from different promoters in the rat brain. Neuroscience 60: 287-291.

Uhl GR, Hall FS, Sora I (2002). Cocaine, reward, movement and monoamine transporters. Mol Psychiatry 7: 21-26.

Uhl GR, Liu QR, Walther D, Hess J, Naiman D (2001). Polysubstance abuse-vulnerability genes: genome scans for association, using 1004 subjects and 1494 single-nucleotide polymorphisms. Am J Hum Genet 69: 1290-1300.

Wiechers B, Gestwa G, Mack A, Carroll P, Zenner HP, Knipper M (1999). A changing pattern of brain-derived neurotrophic factor expression correlates with the rearrangement of fibers during cochlear development of rats and mice. J Neurosci 19: 3033-3042.

Zhou J, Iacovitti L (2000). Mechanisms governing the differentiation of a serotonergic phenotype in culture. Brain Res 877: 37-46. 